\title{
POSSIBLE LOSS OF SOME SPECIES OF THE FAMILY LAMIACEAE FROM THE FLORA OF BANGLADESH
}

\author{
Rashid, M. H. and S. Ahmed \\ Plant Systematics Lab., Department of Botany, University of Chittagong, Chittagong 4331, Bangladesh
}

\begin{abstract}
Present investigation assesses 25 Lamiaceous taxa as possibly Extinct (EX) from the flora of Bangladesh due to various anthropogenic activities. The study based on long term field investigation, examination of preserved herbarium specimens at different national and international herbaria and consultation of relevant floristic literature. These taxa have been previously reported from the area of Bangladesh about 70 to 200 years ago. Since then there have been no subsequent reports of occurrence and no collected specimens are available at any herbaria. Furthermore, this species could not be relocated from elsewhere in Bangladesh. Among these 25 taxa, Leucas mollissima Wall. ex Benth. (=L. decemdentata (Willd.) Sm.) and Elsholtzia incisa Benth. (=E. stachyodes (Link.) Raizada and Saxena) have been reported from the area about 193 and 77 years ago respectively. 18 species (72\%) have been reported from Sylhet; of which, 13 species, viz. Aphanochilus blandus Benth. (=Elsholtzia blanda (Benth.) Benth.), Gomphostemma lucidum Wall. ex Benth., G. melissifolium (Roxb.) Wall. ex Benth., Plectranthus hispidus Benth. (=Isodon hispidus (Benth.) Murata), Plectranthus gerardianus Benth. (=Isodon lophanthoides (Buch.-Ham. ex D. Don) Hara), Leucas vestita Benth., Orthosiphon incurvus Benth., Phlomis rugosa Benth. (=Paraphlomis javanica (Blume) Prain), Geniosporum strobiliferum Wall. ex Benth. (=Platostoma coloratum (D. Don) A.J. Paton), Geniosporum parviflorum Benth. (=Platostoma palustre (Blume) A. J. Paton), Pogostemon parviflorus Benth., Dysophylla strigosa Benth. (=Pogostemon strigosus (Benth.) Benth.), and Scutellaria discolor Wall. ex Benth. were named based on type specimens collected from area by Wallich's collectors, and Microtoenia griffithii Prain was named based on Griffith's collection from East Bengal (current Bangladesh) Sinne loco. Enumeration of these possibly extinct taxa is prepared with data on habit, habitat, phenology, global distribution, recorded localities, specimens examined, and notes with some photographs of type/herbarium specimens.
\end{abstract}

Key words: Lamiaceae, Flora, Extinct, Bangladesh.

\section{INTRODUCTION}

Global biodiversity has been decreasing at an alarming rate and referred to as "biodiversity crisis". Tropical forests has also been seriously imperiled by anthropogenic activities including deforestation and habitat destruction (Novacek and Cleland 2001, Brook et al. 2003). Human impact on nature has reached at such a high proportion that the world is today witnessing an unprecedented rate of species loss. Many more species are disappearing from the nature before their discovery and determination. The 1997 IUCN Red List of Threatened Plants revealed that about 34,000 (12.5\%) of the world's vascular plant species are at risk of extinction (Walter and Gillett 1998). Later the 2004 IUCN Red List includes 11,824 species of plants, of which 8,321 are threatened. Pitman and Jorgensen (2002) stated if following IUCN criteria for proper assessment is done, about $50 \%$ of world's flora might be threatened at risk of extinction. However, only about $4 \%$ of the described plant species have been evaluated so far, of which about 3\% are threatened (Baillie et al. 2004). The IUCN threatened Plants Unit at the Royal Botanical Gardens, Kew, has produced a global data of 50,000 plant species, of which around 20,000 species fall under threatened categories. However, the 'biodiversity crisis' created by human civilization has resulted in drastic reduction and extinction of biodiversity due to disappearance of habitats, pollution and over-exploitation. Over the past half a billion years, the world lost perhaps one species per million each year whereas the current annual rate of extinction is estimated to be 1,000 to 10,000 times faster. By 2050, the biodiversity loss is expected to be equivalent to 7\% of the World's GDP (Braat and ten 
Brink 2008). A conservative estimate of IUCN threatened plant Units shows that about 60,000 plant species (25\%) would become either extinct or nearly extinct by the 2050 (Uberoi 2010). In the current wave of multiple threats, humans cannot predict the impact and consequences of plant extinctions. Even extinction of a single plant species may result in the disappearance of 30 associated species of plants and wildlife (USDA 1993). Recently, Pimm and Joppa (2015) estimated current plant extinction risk which is $27-33 \%$ while Brummit et al. (2015) presumed $21.44 \%$.

Bangladesh is endowed with high plant resources as it lies in a transition of two mega-biodiversity hot spots Indo-Himalayas and Indo-Chinese. However, Bangladesh forests are highly vulnerable to anthropogenic disturbances and climate change (Khan 2003). It has been estimated that out of c.5000 angiosperm species, at least $8-10 \%$ are facing threats to extinction due to habitat loss, population pressure and over-exploitation of natural resources in Bangladesh (Khan 1991, Rahman et al. 2010, Rashid et al. 2014). Nevertheless, to arrest this process there have been no tangible steps taken (Khan et al. 2001). Therefore, it has been accentuated by Khan et al. (2001) and Rahman et al. (2010) that the first and foremost step in this direction is to make complete inventory of the threatened species with assessment of their conservation status in the flora in order to framing and implementing National Conservation Strategies.

The importance of inventory of threatened plants in Bangladesh was first focused on by Khan (1991) with a tentative list of 12 threatened vascular plants. Afterward, in 1997 IUCN Red List of Threatened plants included 24 vascular plant species from Bangladesh. Subsequently, Khan et al. (2001) published Red Data Book of Vascular plants of Bangladesh with 106 threatened plants. Thereafter, Rahman (2003) and Rahman et al. (2010) reported 18 and 58 species respectively as threatened in the wild under different IUCN Categories. However, family wise inventory of the threatened taxa has been initiated for the first time in Bangladesh by Rahman (2013). He listed 69 species (i.e., 13.27\% out of 520) in 13 angiosperm families presumed to be extinct from the flora of Bangladesh.

Lamiaceae (Labiatae), the mint family, is a large family of aromatic herbs and undershrubs containing many useful plants such as sage (Salvia) and mint (Mentha) known for the wealth of species with medicinal properties, which have been used since early times (Harley et al. 2004). The family has cosmopolitan distribution with 236 genera and about 7,173 species (Harley et al. 2004); 233 genera and about 6,870 species (Heywood et al. 2007); 252 genera and 6,800 species (Judd et al. 2008); 238 genera and 6,500 species (Mabberley 2008); and is regarded as being one of the most highly evolved plant families from the viewpoint of floral structure (Hedge 1992). In Bangladesh the family is represented by 86 species under 34 genera (Khanam 2009).

Walter and Gillett (1998) reported 733 Lamiaceous taxa (c.23\%) as threatened all over the world. Ara et al. (2013) assessed Achyrospermum wallichianum (Benth) Benth. ex Hook. f., Gomphostemma mastersii Benth. ex Hook. f., G. melissifolium Wallich ex Benth., G. velutinum Benth. as Endangered (EN) and Microtoena griffithii Prain as Critically Endangered (CR) in the flora of Bangladesh.

While assessing the status of occurrence of all recorded Lamiaceous taxa for determination of their threatened categories, it revealed that 25 taxa have neither been further reported since their first record nor could be relocated from anywhere in Bangladesh including their recorded collection localities. Moreover, no representative specimens of these taxa could be found available in any herbaria. Hence, these taxa are presumed to be lost from the flora of Bangladesh.

\section{MATERIAL AND METHODS}

Determination of the extinct Lamiaceous taxa has been done through long term repeated explorations throughout the flora, examination and consultation of the collected herbarium specimens 
and relevant literature. Previous collection localities of the Lamiaceous taxa, especially botanically rich areas of Chittagong, Cox's Bazar, Chittagong Hill Tracts districts and greater Sylhet have been explored extensively.

Herbarium specimens lodged at different international, national and local herbaria have been examined critically. The relevant and up-to-date floristic literature since Sinclair (1956), such as, Khan and Afza (1968), Khan and Banu (1972), Alam (1988, 1995)), Khan et al. (1984), Huq and Begum (1984), Huq and Khan (1984), Naderuzzaman and Islam (1984), Huq (1988), Khan et al. (1994), Rahman and Hassan (1995), Rahman and Uddin (1997), Yusuf et al. (1997), Dey et al. (1998), Uddin et al. (1998, 2003), Uddin and Rahman (1999), Rashid et al. (2000), Khan and Huq (2001), Rahman et al. (2001), Rashid and Mia (2001), Uddin and Hassan (2004, 2010), Khanam and Hassan (2005), Hossain et al. (2005), Alam et al. (2006), Momen et al. (2006), Khanam and Hassan (2008), Islam et al. (2009), Khanam (2009), Barbhuiya and Gogoi (2010), Tutul et al. (2010), Arefin et al. (2011), Rahman et al. (2010, 2012, 2013), Rahman et al. (2010a), Uddin et al. (2013), Rashid and Chowdhury (2013), Uddin et al. (2015), Arefin et al. (2017) have been consulted to trace the report of collection/occurrence of the Lamiaceous taxa of Bangladesh. In the result the following Latin words e.g. s.l. (Sinne loco) - without locality; s.a. (Sinne anno) - without date; anno - in the year, are used.

\section{RESULTS AND DISCUSSION}

According to the present investigation 25 Lamiaceous taxa belonging to 14 genera were not relocated in their previous recorded localities and or elsewhere in the flora of Bangladesh. Since their first report between more than 70 years to about 200 years, no specimens are available at any herbaria. Among these 25 taxa Leucas decemdentata (Willd.) Sm. (L. mollissima Wall. ex Benth.) and Elsholtzia stachyodes (Link.) Raizada \& Saxena (Elsholtzia incisa Benth.) have been reported from the area 193 and 77 years ago, respectively.

18 species (64\%) have been listed from Sylhet by Nathaniel Wallich. Of which, following eight species viz. Elsholtzia blanda (Benth.) Benth., Gomphostemma lucidum Wall. ex Benth., G. melissifolium (Roxb.) Wall. ex Benth., Isodon hispidus (Benth.) Murata. (Plectranthus hispidus Benth.), I. lophanthoides (Buch.-Ham. ex D. Don) Hara (Plectranthus gerardianus Benth.), Orthosiphon incurvus Benth., Paraphlomis javanica (Blume) Prain (Phlomis rugosa (Benth.) Prain), and Platostoma palustre (Blume) A. J. Paton (Geniosporum parviflorum Benth.) are named based on type specimens collected from Sylhet by Wallich or his collectors. However, G. melissifolium is also recorded by Roxb. (1832) and Hook. f. (1885) from the same locality. Moreover, G. lucidum, Platostoma palustre, and Scutellaria discolor are reported from East Bengal (Current Bangladesh) as well by Grifffith without citing any specific localities; and distributions of $O$. incurvus are also known from Rangamati and Cox's Bazar. The last specimen of this species was collected from Cox's Bazar in 1920 by J. M. Cowan.

Anisochilus pallidus Wall. ex Benth., Colquhounia coccinea Wall., G. lucidum Wall. ex Benth., Isodon coetsa (Buch.-Ham. ex D. Don) Kudo, Microtoenia griffithii Prain, Pogostemon cruciatus (Benth.) Kuntze, and Scutellaria barbata D. Don are only known from Griffith's collection from East Bengal (current Bangladesh - without citing specific localities). William Griffith made exploration in this area during 1835-36. Since then there have been neither further reports of occurrence of these species in Bangladesh nor any specimen available at any herbaria. However, earlier G. lucidum is named by Wallich based on type specimen collected from Sylhet in 1822.

Hooker (1885), Heinig (1925) and Mukerjee (1940) reported Elsholtzia stachyodes (Link.) Raizada and Saxena (E. incisa Benth.) from Chittagong; Gomphostemma parviflorum var. farinosum Prain is only known from the single specimen collected by Cowan (1920) from Chittagong; and Orthosiphon 
rubicundus (D. Don) Benth. is reported from Chittagong by Heinig (1925). There have been no further reports of occurrence of these taxa since their last record and no specimen is available in any herbaria.

Considering the IUCN criteria (IUCN 2012) these 25 taxa have been assessed as possibly lost from the flora of Bangladesh.

\section{Enumeration of the possibly extinct Lamiaceous taxa of Bangladesh}

Anisochilus pallidus Wall. ex Benth., Pl. As. Rar. 2:18 (1830). Prain (1903); Khanam and Hassan (2008); Khanam (2009). Fig. 1a

An erect herb up to $1 \mathrm{~m}$ high. Habitat: Forest areas; Fl. \& Fr.: October to March.

Global distribution: Nepal, Bhutan, India, Myanmar, Laos, Vietnam, China (Khanam and Hassan 2008). Recorded localities: East Bengal (Bangladesh) Sine loco; Status of occurrence: Possibly Extinct (EX). Specimen examined: East Bengal (Bangladesh): s.l., sine anno (s.a.), Griffith s.n. (CAL).

Conservation status: This species is only known from Griffith's collection from East Bengal (current Bangladesh - specific locality is not cited) lodged at Central National Herbarium Kolkata (CAL). William Griffith's exploration was made in this area during 1835-36. Since then there has been no further report of occurrence of this species in Bangladesh and no specimen is available at any herbaria. Moreover, this species could not be relocated or collected from elsewhere Bangladesh.

Colquhounia coccinea Wall., Trans. Linn. Soc. London 13: 608 (1822). Khanam and Hassan (2008); Khanam (2009). Fig. 1b

A tall shrub, up to 3m high. Habitat: Forest areas; Fl. \& Fr.: During winter season.

Global distribution: India, Myanmar, Nepal, Bhutan, Thailand, Tibet, (Khanam and Hassan 2008).

Recorded localities: East Bengal (Bangladesh) Sine loco; Status of occurrence: Presumed Extinct (EX).

Specimen examined: East Bengal (Bangladesh): s.l., s.a., Griffith 4028 (CAL).

Conservation status: The species is only known from Griffith's collection from East Bengal (current Bangladesh - specific locality is not cited) preserved at Central National Herbarium Kolkata (CAL). William Griffith made the exploration in the area during 1835-36. Since then there has been no further report of occurrence and no collection at any herbaria. Furthermore, this species could not be relocated or collected from elsewhere Bangladesh.

Elsholtzia blanda (Benth.) Benth., Labiat. Gen. Spec. 162 (1833). Khanam \& Hassan (2008); Khanam (2009). Aphanochilus blandus Benth. (1830). Fig. 1c

An undershrub or herb, 60 to 100cm high. Habitat: Edges of forests; Fl. \& Fr.: March to September Global distribution: Continental Southeast Asia, Nepal, India, Myanmar, Thailand, South China and Malaysia (Khanam and Hassan 2008).

Recorded localities: Sylhet; Status of occurrence: Possibly Extinct (EX).

Specimens examined: Sylhet (Sillet): anno 1829, Wallich, Wall. Cat. n. 1550/b (Syntypes K000881697!, E00301391!, E00301392!)

Conservation status: This species is only known from Wallich's type specimen collected by Francis de Silva from Sylhet in 1829. Since then there has been no further report of its occurrence in Bangladesh and no specimen is available at any herbaria. Moreover, this species could not be relocated or collected from its recorded locality or from elsewhere Bangladesh.

Elsholtzia flava (Benth.) Benth., Labiat. Gen. Spec. 161 (1833). Khanam \& Hassan (2008); Khanam (2009). Aphanochilus flavus Benth. (1829). Fig. 1d

A shrub, 100-150cm high. Habitat: Edges of forests; Fl. \& Fr.: October to June 
Global distribution: Pakistan, India and Nepal (Khanam \& Hassan 2008).

Recorded localities: Sylhet; Status of occurrence: Presumed Extinct (EX).

Specimens examined: Sylhet (Sillet): anno 1829, Francis de Silva, Wall. Cat. n.1550 (E00301390!).

Conservation status: This species is only known from Wallich's specimen collected by Francis de Silva from Sylhet in 1829. Since then there has been no further report of its occurrence in Bangladesh and no specimen is available at any herbaria. Furthermore, this species could not be relocated or collected from its recorded locality or from elsewhere Bangladesh.

Elsholtzia stachyodes (Link.) Raizada \& Saxena, Ind. For. 92: 309 (1966). Khanam and Hassan (2008); Khanam (2009). Hyptis stachyodes Link. (1822). Elsholtzia incisa Benth. (1833); Hooker, f. (1885); Heinig (1925); Mukerjee (1940).

A slender herb, up to $1 \mathrm{~m}$ high, strongly aromatic. Habitat: The edges of rain forest; Fl. \& Fr.: July to October

Global distribution: India, Nepal and Myanmar, Thailand (Khanam and Hassan 2008).

Recorded localities: Chittagong; Status of occurrence: Possibly Extinct (EX)

Specimens examined: No specimen is available at any herbaria.

Conservation status: This species was reported from Chittagong by J. D. Hooker in 1885, Heinig in 1925 and lastly in 1940 by Mukerjee. Since Mukerjee (1940) there has been no further report of occurrence of this species in Bangladesh and no specimen is available at any herbaria. Moreover, this species could not be relocated or collected from its recorded locality or from elsewhere Bangladesh.

Gomphostemma lucidum Wall. ex Benth., Pl. As. Rar. 2: 12 (1830). Hook. f. (1885); Khanam and Hassan (2008); Khanam (2009). Fig. 1e

A robust herb about 1-1.2m high. Habitat: Along slopes of hills; Fl. \& Fr.: September to April. Global distribution: India (Khanam and Hassan 2008).

Recorded localities: Sylhet; Status of occurrence: Presumed Extinct (EX).

Specimens examined: East Bengal (Bangladesh): s.l., s.a., Griffith 4038 (CAL); Sylhet (Sillet): s.a., Francis de Silva, Wall. Cat. n. 2156/2 (Type K001115340!).

Conservation status: This species is only known in Bangladesh from Wallich's type specimen collected by Francis de Silva from Sylhet in 1822 and Griffith's collection from East Bengal (current Bangladesh - specific locality is not cited) during 1835-36. Since then there has been no further report of occurrence of this species in Bangladesh and no specimen is available at any herbaria. Furthermore, this species could not be relocated or collected from its recorded locality or from elsewhere Bangladesh.

Gomphostemma melissifolium Wall. ex Benth., Pl. As. Rar. 2:12 (1830). Khanam and Hassan (2008); Khanam (2009). Prasium melissifolium Roxb. (1832). Fig. $2 \mathrm{f}$

A prostrate or scandent herb, 0.5-2.5m high. Habitat: Slope of hills and near the stream in forests; Fl. \& Fr.: September to April

Global distribution: India (Khanam and Hassan 2008).

Recorded localities: Sylhet; Status of occurrence: Probably Extinct (EX).

Specimens examined: Sylhet (Sillet): anno 1824, Wallich, Wall. Cat. n. 2157 (Isotypes K000928178!, BM000521976!, G00189095!).

Conservation status: This species is only known from type specimen collected by Francis de Silva from Sylhet and listed in Wallich's catalogue. Subsequently, Roxb. (1832) and Hooker (1885) also reported the species from the same locality. Since Hooker (1885) there has been no further report of its 
occurrence in Bangladesh and no specimen is available at any herbaria. Moreover, this species could not be relocated or collected from its recorded locality or from elsewhere Bangladesh.

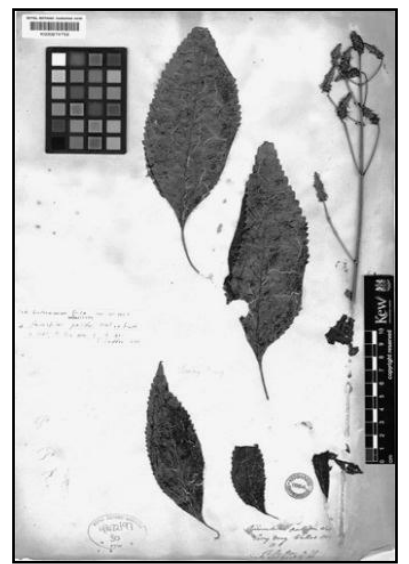

$\mathrm{a}$

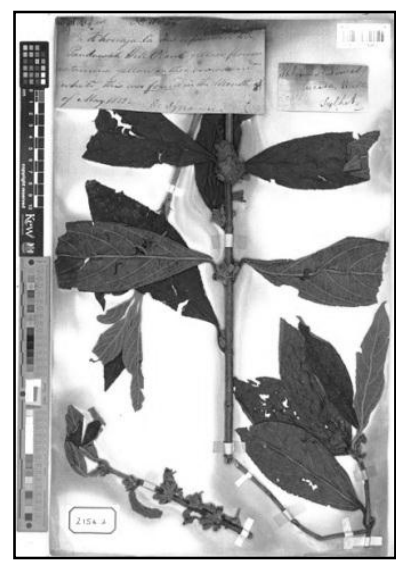

$\mathrm{e}$

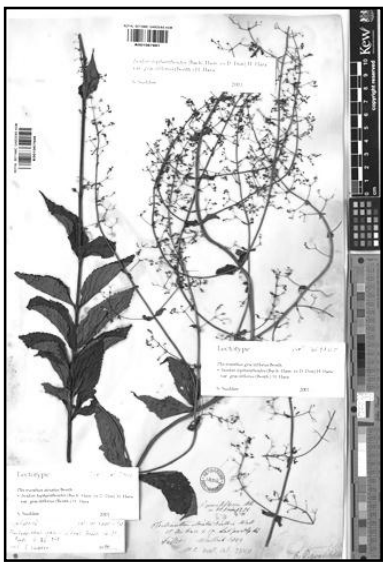

i

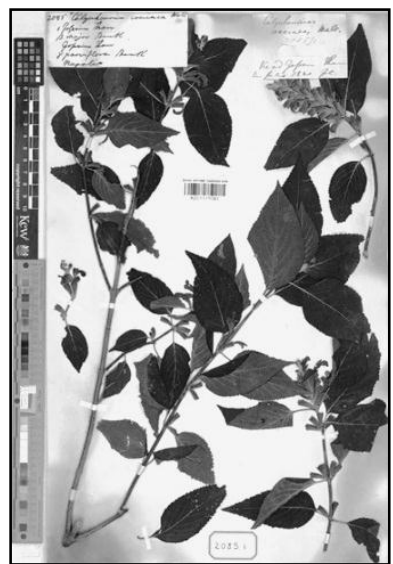

b

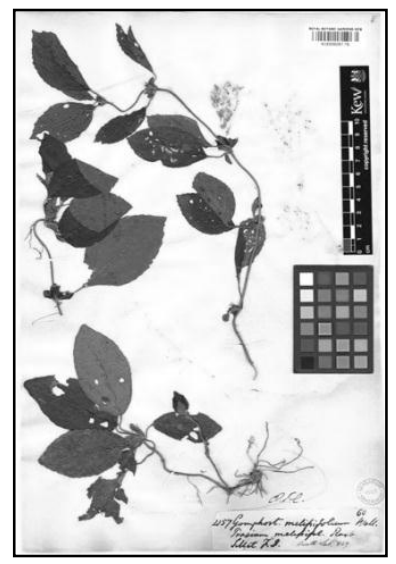

$\mathrm{f}$

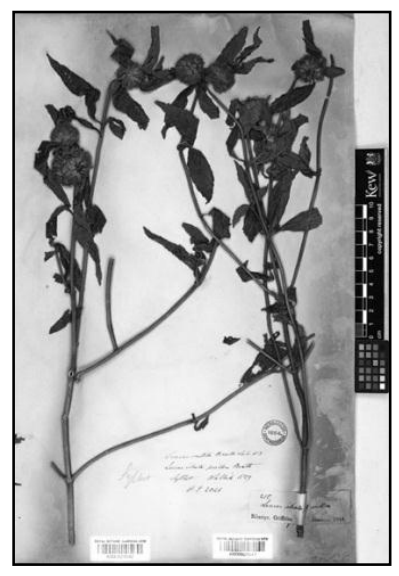

$\mathrm{j}$

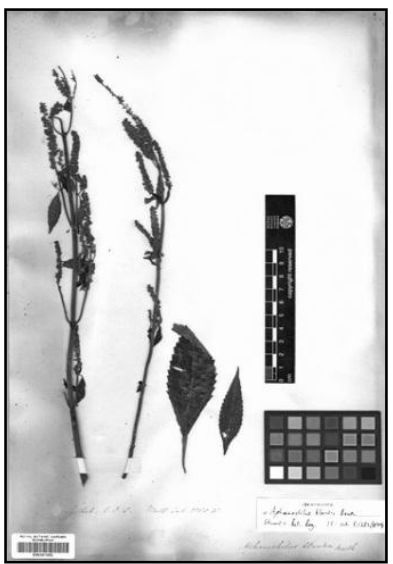

$\mathrm{c}$

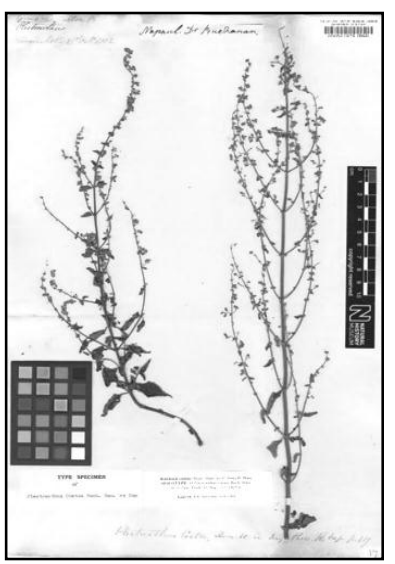

g

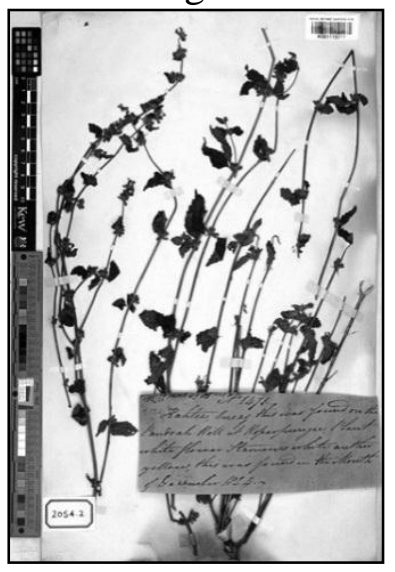

$\mathrm{k}$

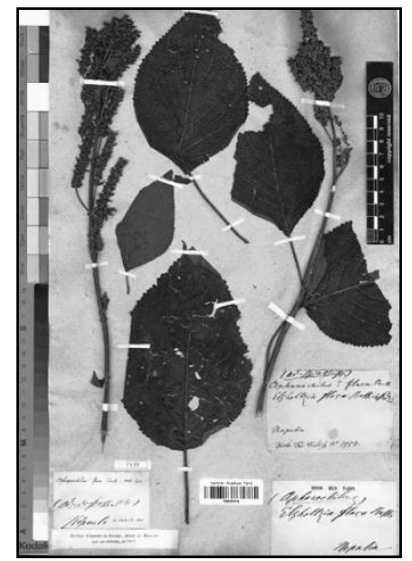

d

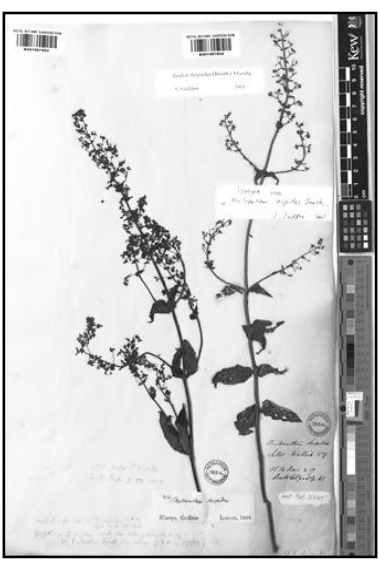

$\mathrm{h}$

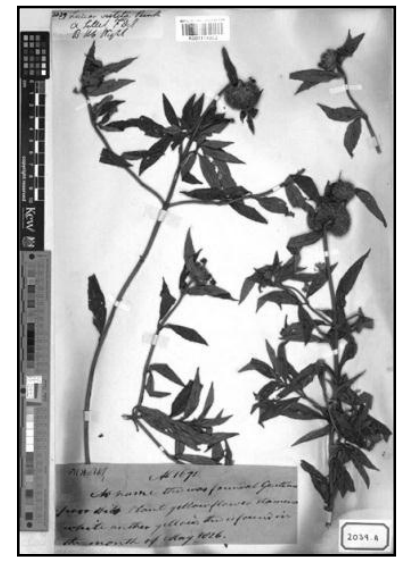

1

Fig. 1. Plant type: a. Aniosochilus pallidus (K000674759), b. Colquhounia coccinea (K001115081), c. Elsholtzia blanda (E00301392), d. Elsholtzia flava (P00737619), e. Gomphostemma lucidum (K001115340), f. Gomphostemma melissifolium (K000928178), g. I. coetsa (BM000521976), h. Syntype of I. hispidus (K 001067854), i. Isodon lophanthoides (K001067881), j. Leucas ciliata (K000929541), k. Leucas decemdentata (K001115011), 1. Leucas vestita (K001114953). 


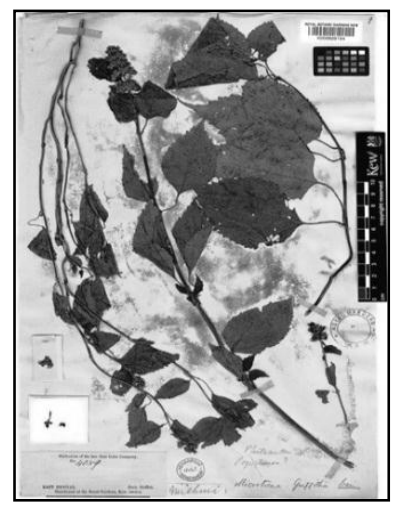

$\mathrm{a}$

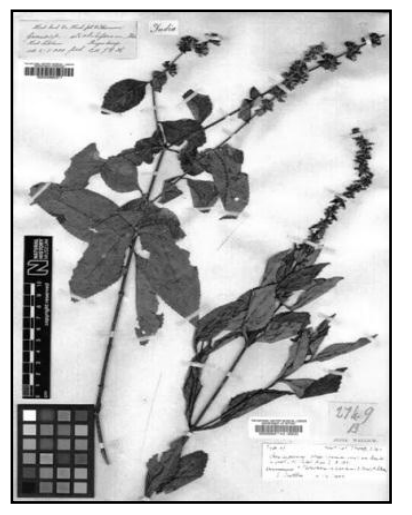

e

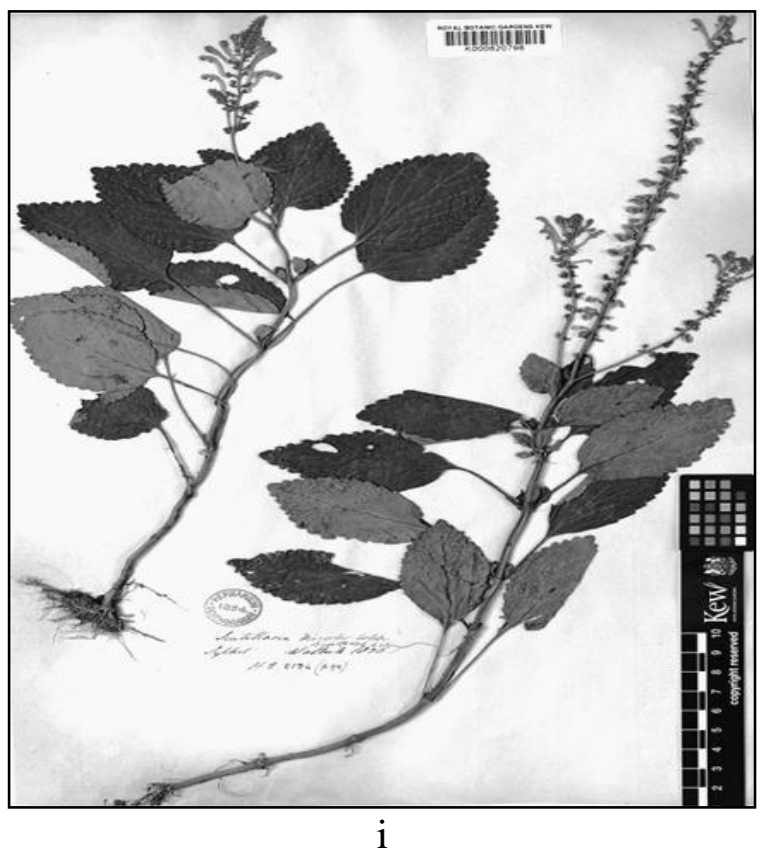

$\mathrm{f}$

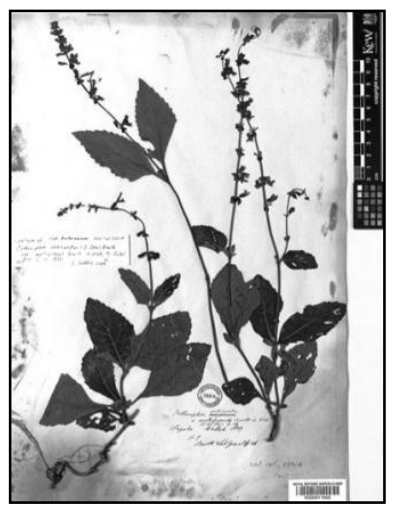

C
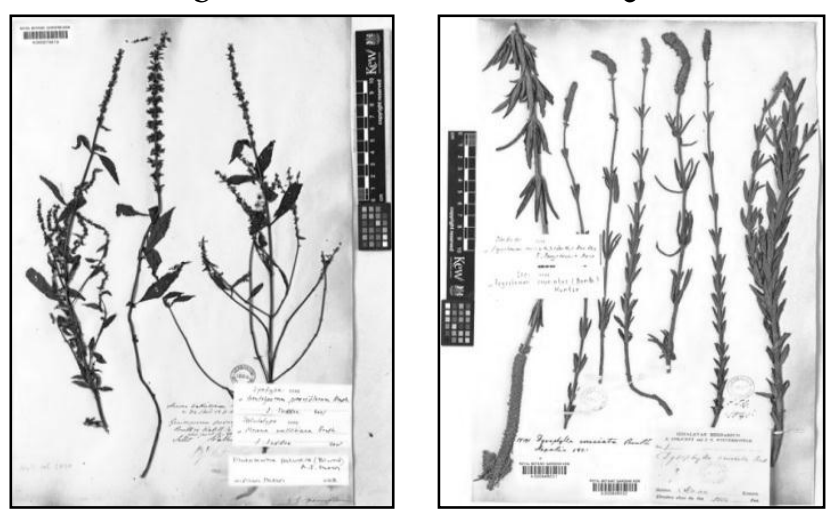

g

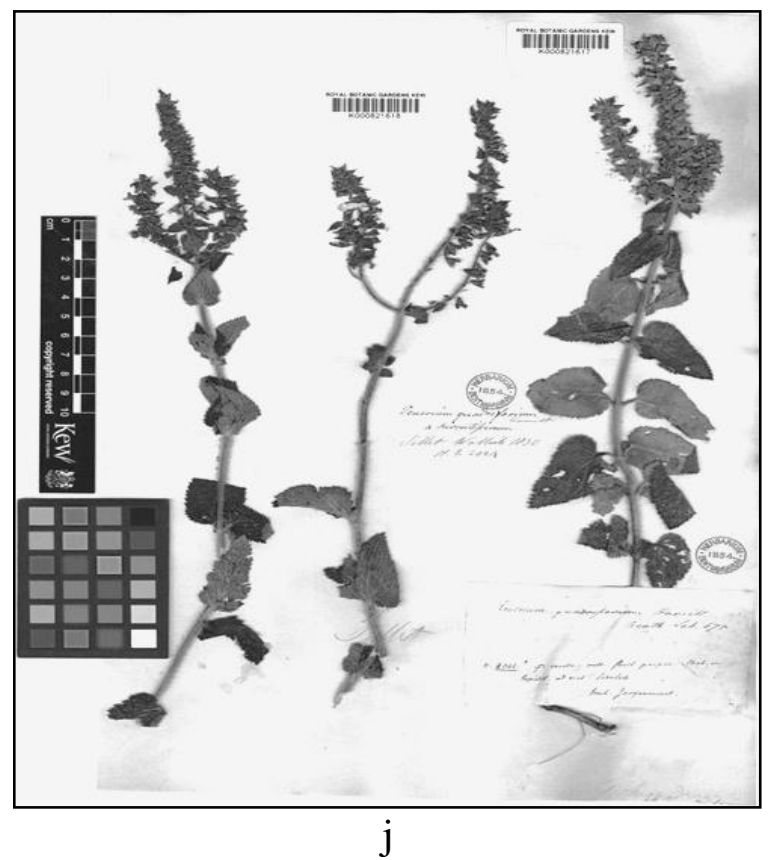

Fig. 2. Plant type: a. Mirotoena griffithii (K000928194), b. Syntype of Orthosiphon incurvus (K001116954), c. Orthosiphon rubicundus (K000911655), d. Lectotype of Paraphlomis javanica (K000898661), e. Platostoma coloratum (BM000950317), f. Syntype of Platostoma palustre (K000674619), g. Pogostemon cruciatus (K000848031), h. Pogostemon strigosus (K000848028), i. Syntype of Scutellaria discolor (K000820798) and j. Teucrium quadrifarium (K000821617). 
Gomphostemma parviflorum var. farinosum Prain, Ann. Roy. Bot. Gard. (Calcutta) 3: 253 (1891).

An erect herb, 2.5-3.0m high. Habitat: Waste places; Fl. \& Fr.: September to August

Global distribution: India and China (Khanam and Hassan 2008).

Recorded localities: Chittagong; Status of occurrence: Possibly Extinct (EX).

Specimens examined: Chittagong: Matamori, M. R. Range, 29.09.1920, J. M. Cowan, 855 (E).

Conservation status: this taxon is only known in Bangladesh from the single specimen preserved at Herbarium, Royal Botanic Gardens Edinburgh (E) collected by J. M. Cowan in 1920 from Chittagong. Since then there has neither been any specimen nor its further report from Bangladesh is available. This could not be relocated or collected from its recorded locality or from elsewhere Bangladesh.

Isodon coetsa (Buch.-Ham. ex D. Don) Kudô, Mem. Fac. Sci. Agr. Taihoku Imp. Univ. 2: 131 (1929). Khanam and Hassan (2008); Khanam(2009). Plectranthus coetsa Buch.-Ham. ex D. Don (1825). Fig. 1g

An erect, perennial, strongly aromatic undershrub, 1.0-2.5cm high. Habitat: Hilly region; Fl. \& Fr.: September to December.

Global distribution: India, Sri Lanka, Myanmar and Bangladesh (Khanam and Hassan 2008).

Recorded localities: East Bengal (Bangladesh) Sine loco; Status of occurrence: Probably Extinct (EX). Specimens examined: East Bengal (Bangladesh): s.l., s.a., Griffith 3959 (CAL).

Conservation status: This species is first known from William Griffith's collection from East Bengal (now Bangladesh) deposited at Central National Herbarium Kolkata (CAL). However, specific collection locality and date are not mentioned on the herbarium sheet. Griffith's exploration was made in the area during 1835-36. Since then there has been no further report of in Bangladesh and no specimen preserved at any herbaria. This species could not be relocated or collected from elsewhere Bangladesh.

Isodon hispidus (Benth.) Murata, Act. Phytotax. Geobot. 24: 82 (1969). Khanam and Hassan (2008); Khanam (2009). Plectranthus hispidus Benth. (1831). Hook. f., (1885). Fig. 1h

A stout herb, 1.0-2.5cm high. Habitat: Evergreen forests; Fl. \& Fr.: September to February.

Global distribution: India and Myanmar (Khanam and Hassan 2008).

Recorded localities: Sylhet; Status of occurrence: Presumed Extinct (EX).

Specimens examined: Sylhet (Sillet): anno 1831, Francis de Silva, Wall. Cat. n. 2741 (Syntypes K001067854!, CAL!).

Conservation status: This species is only known from the type specimen collected from Sylhet in 1831 by Francis de Silva and deposited at Royal Botanic Garden Herbarium Kew (K) and Central National Herbarium Kolkata (CAL). Since then there has been no further report of its occurrence in Bangladesh and no specimen is available at any herbaria. Furthermore, this species could not be relocated or collected from its recorded locality or from elsewhere Bangladesh.

Isodon lophanthoides (Buch.-Ham. ex D. Don) Hara, Journ. Jap. Bot. 60: 235 (1985). Khanam and Hassan (2008); Khanam (2009). Hyssopus lophanthoides Buch.-Ham. ex D. Don (1825); Plectranthus gerardianus Benth. (1830); Plectranthus stocksii Hook.f. (1885). Fig. 1i

A small herb. Habitat: Dry soil inside the forests; Fl. \& Fr.: September to February.

Global distribution: Bhutan, India and Myanmar (Khanam and Hassan 2008).

Recorded localities: Sylhet; Status of occurrence: Possibly Extinct (EX).

Species examined: Sylhet: Mont. Sillet (Sylhet), anno 1829, William Bruce., Wall. Cat. n. 2740 (Lectotypes K0011067856!, K001067881!, K001067946!, Isolectotype E00273786!). 
Conservation status: This species is only from type specimen collected from Sylhet in 1829. Since then there has been no further report of its occurrence in Bangladesh and no specimen is available at any herbaria. Moreover, this species could not be relocated or collected from its recorded locality or from elsewhere Bangladesh.

Leucas ciliata Benth., Pl. As. Rar. 1: 61 (1830); Khanam and Hassan (2008); Khanam (2009). Fig. 1j Local name: Shetodron.

A tall robust herb, up to $0.3-1.0 \mathrm{~m}$ high. Habitat: Waste marshy places; Fl. \& Fr.: April to December Global distribution: Nepal, Bhutan, India and Myanmar (Khanam and Hassan 2008).

Recorded localities: Sylhet; Status of occurrence: Probably Extinct (EX).

Specimens examined: Sylhet: anno1829, Wall. Cat. n. 2046/B (K000929541).

Conservation status: This species is only from single specimen collected from Sylhet in 1829, preserved at the Royal Botanic Garden Kew Herbarium (K). Since then there is neither its report of occurrence in Bangladesh nor any specimen found at any herbaria. Furthermore, this species could not be relocated or collected from its recorded locality or from elsewhere Bangladesh.

Leucas decemdentata (Willd.) Sm., Cycl. 20 (2): 6 (1812). Fig. 1k

Phlomis decemdentata Willd. (1800); Leucas mollissima Wall. ex Benth. (1830). Khanam and Hassan (2008); Khanam (2009).

A slender herb with straggling branches. Habitat: Dry soil, along roadside; Fl. \& Fr.: January to July. Global distribution: India, Malaysia, China and Sri Lanka (Khanam and Hassan 2008).

Recorded localities: Sylhet; Status of occurrence: Presumed Extinct (EX).

Specimens examined: Sylhet: Pandoah Hill, December 1824, Wall. Cat. n. 2054/2 (K001115011).

Conservation status: This species is only known from Wallich's specimen collected from Pandoah hill, Sylhet in 1824. Since then there has been no further report of its occurrence in Bangladesh and no specimen is available at any herbaria. Moreover, this species could not be relocated or collected from its recorded locality or from elsewhere Bangladesh.

Leucas vestita Benth., Pl. As. Rar.1: 61 (1830). Khanam and Hassan (2008); Khanam (2009). Fig. 11

A tall herb. Habitat: Dry soil in grasslands; Fl. \& Fr.: January to July.

Global distribution: India.

Recorded localities: Sylhet; Status of occurrence: Possibly Extinct (EX).

Specimens examined: Sylhet (Sillet): May 1826, Francis de Silva, Wall. Cat. n. 2039/a (Type K001114953!).

Conservation status: This species is only known from Wallich's collection from Sylhet by Francis de Silva in May 1826; housed at the Royal Botanic Garden Kew Herbarium (K), and Central National Herbarium Kolkata (CAL). Since then there has been no further report of its occurrence in Bangladesh and no specimen is available at any herbaria. Furthermore, this species could not be relocated or collected from its recorded locality or from elsewhere Bangladesh.

Microtoena griffithii Prain, J. Asiat. Soc. Bengal, Pt. 2, Nat. Hist. 59(2): 310 (1896). Khanam and Hassan (2008); Khanam (2009). Fig. 2a

An erect herb, up to m high, glabrescent. Habitat: Waste places; Fl. \& Fr.: October to June. Global distribution: India (Assam) (Khanam and Hassan 2008).

Recorded localities: East Bengal (Bangladesh) Sine loco; Status of occurrence: Presumed Extinct (EX). 
Specimens examined: East Bengal (Bangladesh): s.l., s.a., Griffith 4059 (Type K000928194!).

Conservation status: The species is only known from Griffith's collection from East Bengal (current Bangladesh - specific locality is not cited) preserved at Royal Botanic Garden Herbarium Kew (K) and Central National Herbarium Kolkata (CAL). William Griffith's exploration was made in the area during 1835-36. Since then there has been no further report of occurrence in Bangladesh and no specimen is available at any herbaria. Moreover, this species could not be relocated or collected from elsewhere Bangladesh.

Orthosiphon incurvus Benth., Pl. As. Rar. 2:15(1830). Khanam and Hassan (2008); Khanam (2009). Fig. 2b

An undershrub or shrub, up to $1 \mathrm{~m}$ high. Habitat: Dry soil in forest areas; Fl. \& Fr:: March to October. Global distribution: India, Sikkim, Myanmar, and Nepal (Khanam and Hassan 2008).

Recorded localities: Cox's Bazar, Rangamati and Sylhet; Status of occurrence: Presumed Extinct (EX). Specimens examined: Cox's Bazar: Garjania, June, 1920, Cowan 563 (E). Rangamati: Dmagiri S. West, 22.03.1876, Lister 268 (CAL); Kaptai, 07.10.1905, D. Hooper 26097 (E, CAL); Janglibag, 7.10.1905, D. Hooper 25043 (CAL). Sylhet: anno 1830, William Bruce, Wall. Cat. n. 2725 (Syntypes K001116954!, K000911667!, BM000588744!); .

Conservation status: Since its last collection in 1920 by J.M. Cowan from Garjania, Cox's Bazar there has been no further report of occurrence and no specimen is available at any herbaria. Furthermore, this species could not be relocated or collected from its recorded locality or from elsewhere Bangladesh.

Orthosiphon rubicundus (D. Don) Benth., Pl. As. Rar. 2: 14 (1830). Prain (1903); Heinig (1925); Khanam and Hassan (2008); Khanam (2009). Fig. 2c

Plectranthus rubicundus D. Don (1825).

An erect herb, up to 30-60cm high. Habitat: Forests; Fl. \& Fr.: April-June.

Ecology: Growing inside the forests.

Global distribution: India, Myanmar, Nepal (Khanam and Hassan 2008).

Recorded localities: Chittagong; Status of occurrence: Possibly Extinct (EX).

Specimens examined: No specimen is available at any herbaria.

Conservation status: This species is reported from Chittagong by Heinig (1925). Since then there has been no report of occurrence of this species and no specimen is available at any herbaria. Moreover, this species could not be relocated or collected from its recorded locality or from elsewhere Bangladesh.

Paraphlomis javanica (Blume) Prain, Ann. Roy. Bot. Gard. (Calcutta) 9: 60 (1901).

Leonurus javanicus Blume (1823); Paraphlomis rugosa (Benth.) Prain (1901). Khanam and Hassan (2008); Khanam (2009); Phlomis rugosa Benth. (1830). Fig. 2d

A small almost glabrous herb. Habitat: Dry soil; Fl. \& Fr.: During winter season.

Global distribution: India, China, Thailand, Philippines Malaysia (Khanam and Hassan 2008).

Recorded localities: Sylhet; Status of occurrence: Presumed Extinct (EX).

Specimens examined: Sylhet (Sillet): anno 1829, Wallich, Wall. Cat. n. 2067 (Lectotype K000898661!). Conservation status: This species is only known from Wallich's type specimen collected from Sylhet in 1829 and lodged at the Royal Botanic Garden Kew Herbarium (K). Since then there has been no further report of its occurrence in Bangladesh and no specimen is available at any herbaria. Furthermore, this species could not be relocated or collected from its recorded locality or from elsewhere Bangladesh. 
Platostoma coloratum (D. Don) A.J.Paton, Kew Bull. 52: 274 (1997).

Geniosporum coloratum (D. Don) Kuntze (1891). Khanam and Hassan (2008); Khanam (2009).

Plectrunthus coloratus D. Don (1825); Geniosporum strobiliferum Wall. ex Benth. (1830). Fig. 2e

An erect herb, up to 1m tall. Habitat: Waste places; Fl. \& Fr.: April to October.

Global distribution: India, Bhutan, Nepal, and South-West China (Khanam and Hassan 2008).

Recorded localities: Sylhet; Status of occurrence: Presumed Extinct (EX).

Specimens examined: Sylhet (Sillet): anno 1831, William Bruce, Wall. Cat. N. 2749/B (Holotype K000674624!, Isotype BM000588749/B!).

Conservation status: This species is only known from Wallich's specimen collected from Sylhet in 1830 and lodged at the Royal Botanic Garden Kew Herbarium (K) and Natural History Museum London (BM). Since then there has been no further report of its occurrence in Bangladesh and no specimen is available at any herbaria. Moreover, this species could not be relocated or collected from its recorded locality or from elsewhere Bangladesh.

Platostoma palustre (Blume) A. J. Paton, Kew Bull. 52: 281 (1997).

Mesona palustris Blume (1826); Geniosporum parviflorum Benth. (1830). Khanam and Hassan (2008); Khanam (2009). Fig. $2 \mathrm{f}$

A slender herb, 30 - 60cm high. Habitat: Along forest area; Fl. \& Fr.: March to November

Global distribution: India (Assam) and Myamar (Khanam and Hassan 2008).

Recorded localities: Sylhet; Status of occurrence: Possibly Extinct (EX).

Specimens examined: East Bengal (Bangladesh): s.l., s.a., Griffith 3946/1 (CAL). Sylhet (Sillet): anno 1830, Wallich, Wall. Cat. n. 2750 (Syntypes K000674619!, BM000588478!).

Conservation status: This species is only known from Wallich's type specimen collected from Sylhet in 1830 and Griffith's collection from East Bengal (current Bangladesh - specific locality is not cited). William Griffith's exploration was done in the area during 1835-36. Since then there has been no further report of its occurrence in Bangladesh and no specimen is available at any herbaria. Furthermore, this species could not be relocated or collected from its recorded locality or from elsewhere Bangladesh.

Pogostemon cruciatus (Benth.) Kuntze, Revis. Gen. Pl. 2: 530 (1891). Khanam and Hassan (2008); Khanam (2009). Dysophylla cruciata Benth. (1830). Fig. $2 \mathrm{~g}$

An erect hirsute herb, about $45 \mathrm{~cm}$ high. Habitat: On dry soil; Fl. \& Fr.: October to March. Global distribution: India, Myanmar and China.

Recorded localities: East Bengal (Bangladesh) Sine loco; Status of occurrence: Presumed Extinct (EX). Specimen examined: East Bengal (Bangladesh): s.l., s.a., Griffith 3969 (K).

Conservation status: The species is only known from Griffith's collection from East Bengal (current Bangladesh - specific locality is not cited) preserved at the Royal Botanic Garden Kew Herbarium (K). William Griffith's exploration was done in the area during 1835-36. Since then there has been no further report of occurrence and no collection at any herbaria. Moreover, this species could not be relocated or collected from elsewhere Bangladesh.

Pogostemon strigosus (Benth.) Benth., Prodr. 12: 155 (1848). Khanam and Hassan (2008); Khanam (2009). Dysophylla strigosa Benth. (1830). Fig. 2h

An erect herb, 60-80cm high. Habitat: On moist places in forests; Fl. \& Fr.: March to June. Global distribution: India (Khasia) and Myanmar (Khanam and Hassan 2008).

Recorded localities: Sylhet; Status of occurrence: Possibly Extinct (EX). 
Specimens examined: Sylhet (Sillet): anno 1829, Francis de Silva, Wall. Cat. n. 1549 (Type K000848028!).

Conservation status: This species is only known from Wallich's type specimen collected from Sylhet in 1829. Since then there has been neither further report of its occurrence in Bangladesh nor any specimen is available at any herbaria. Furthermore, this species could not be relocated or collected from its recorded locality or from elsewhere Bangladesh.

Scutellaria barbata D. Don, Prodr. Fl. Nepal. 109 (1825).

Scutellaria rivularis Wall. ex Benth. (1831); Khanam and Hassan (2008); Khanam (2009).

An ascending herb, up to 15-20cm high. Habitat: moist places in forests; Fl. \& Fr:. October to February. Global distribution: India, Sri Lanka, Myanmar and Bangladesh.

Recorded localities: East Bengal (Bangladesh) Sine loco; Status of occurrence: Presumed Extinct (EX). Specimens examined: East Bengal (Bangladesh): s.l., s.a., Griffith 4018 (CAL). Gangachora, 26.04.1809, S. Coll., Wall. Cat. n. 2140/C (K).

Conservation status: The species is only known from Wallich's collection from Gangachora in 1809 and Griffith's collection from East Bengal (current Bangladesh - specific locality is not cited) preserved at Central National Herbarium Kolkata (CAL). William Griffith made his collections in the area during 1835-36. Since then there has been no further report of its occurrence in Bangladesh and no specimen is available at any herbaria. Moreover, this species could not be relocated or collected from its recorded locality or from elsewhere Bangladesh.

Scutellaria discolor Colebr., Pl. As. Rar. 1:66(1830). Khanam and Hassan (2008); Khanam (2009). Fig. 2i

An an nnual herb, $20-60 \mathrm{~cm}$ high. Habitat: streams, shady and moist places in forests; Fl. \& Fr.: September to February.

Global distribution: India, China, Thailand, Malaysia and Myanmar (Khanam and Hassan 2008).

Recorded localities: Sylhet; Status of occurrence: Possibly Extinct (EX).

Specimens examined: East Bengal (Bangladesh): s.l., s.a., Griffith 4017 (CAL); Sylhet: anno 1830, Francis de Silva, Wall. Cat. n. 2134/2 (Syntype K000820798!); 10.10.1872, C. B. Clarke 18504 (CAL). Conservation status: This species is known from Wallich's type specimen collected from Sylhet in 1829. The last report of its occurrence in Sylhet was done by C. B. Clarke from Sylhet in 1872. Since then there has been no further report of its occurrence in Bangladesh and no specimen is available at any herbaria. Moreover, this species could not be relocated or collected from its recorded locality or from elsewhere Bangladesh.

Teucrium quadrifarium Buch.-Ham., Prodr. Fl. Nepal. 108 (1825). Hook. f. (1885); Khanam and Hassan (2008); Khanam (2009). Fig. 2j

An erect perennial herb, stem hirsute. Habitat: Waste marshy places, forest slopes; Fl. \& Fr.: March-June. Global distribution: India, Indonesia (Sumatra), Myanmar, Nepal and China.

Recorded localities: Sylhet; Status of occurrence: Presumed Extinct (EX).

Specimens examined: Sylhet: anno 1830, Francis de Silva, Wall. Cat. n. 2029 (K000821618).

Conservation status: This species is only known from Wallich's collection made by Francis de Silva in 1830 from Sylhet. Since then there has been no further report of its occurrence in Bangladesh and no specimen is available at any herbaria. Moreover, this species could not be relocated or collected from its recorded locality or from elsewhere Bangladesh. 


\section{ACKNOWLEDGEMENTS}

The authors would like to express sincere thanks to the directors/curators of different herbaria for making the specimens available, provide the library facilities and to access the type photographs. They also grateful to the Research and Publication Cell, University of Chittagong for financial assistance.

\section{REFERENCES}

Alam, M. K. 1988. An annotated checklist of the woody flora of Sylhet forest. Forestry Bull. 5: 115119.

Alam, M. K. 1995. Diversity in the woody Flora of Sal (Shorea robusta) Forest of Bangladesh. Bangladesh J. Forest Sci. 24(1): 41-51.

Alam, M. S., M. A. Hassan and M. Z. Uddin. 2006. A Preliminary Check list of the angiospermic flora of Ghagotia Union under Kapasia Upazila in Gazipur District, Bangladesh. Bangladesh J. Plant Taxon. 13(2): 155-170.

Ara, H., B. Khan and S. N. Uddin (eds.). 2013. Red Data Book of Vascular Plants of Bangladesh. Vol 2. Bangladesh National Herbarium, Dhaka, Bangladesh, pp. 1-280.

Arefin, M. K., M. M. Rahman, M. Z. Uddin and M. A. Hassan. 2011. Angiospermic Flora of Satchari National Park, Habiganj, Bangladesh. Bangladesh J. Plant Taxon. 18(2): 117-140.

Arefin, M. S., M. K. Hossain and M. A. Hossain. 2017. Plant diversity of Sonadia Island - An ecologically critical area of South-east Bangladesh. Bangladesh J. Plant Taxon. 24(1): 107-116.

Baillie, J. E. M., C. Hilton-Taylor and S. N. Stuart (eds.). 2004. IUCN Red List of threatened Species: A Global Species Assessment. IUCN, Gland, Switzerland and Cambridge, UK, pp. 1-191.

Barbhuiya, H. A. and R. Gogoi. 2010. Plant collections from Bangladesh in the Herbarium at Shillong (Assam), India. Bangladesh J. Plant Taxon. 17(2): 141-165.

Braat L. and P. ten Brink (eds.). 2008. The Cost of Policy Inaction (COPI): The case of not meeting the 2010 biodiversity target. EC Report. Alterra, Wageiningen, 314 pp.

Brook, B. W., N. S. Sodhi and P. K. L. Ng. 2003. Catastrophic extinctions follow deforestation in Singapore. Nature. 424: 420-423.

Brummitt, N. A., S. P. Bachman, J. Griffiths-Lee, M. Lutz, J. F. Moat, A. Farjon, J. S. Donaldson, C. Hilton-Taylor, T. R. Meagher and S. Albuquerque. 2015. Green plants in the red: a baseline global assessment for the IUCN Sampled Red List Index for Plants. PLoSONE. 10(8): 135-152.

Cowan, J. M. 1926. The Flora of Chakaria Sundarbans. Rec. Bot. Surv. Ind. Calcutta. 11(2): 197-226.

Dey, C. K., M. A. Rahman and C. C. Wilcock. 1998. An enumeration of the Tree species of Chittagong district. Biodiv. Bull. Bangladesh. 1: 70-73.

Harley, R. M, S. Atkins, A. L. Budantsev, P. D. Cantino, B. J. Conn, R. Grayer, M. M. Harley, R. de Kok, T. Krestovskaja, R. Morales, A. J. Paton, O. Ryding and T. Upson. 2004. Labiatae. In: J. W. Kadereit and K. Kubitzki, (ed.). The Families and Genera of Vascular Plants. Vol. VII. SpringerVerlag, Berlin, pp. 167-275.

Hedge, I. C. 1992. A global survey of the biogeography of the Labiatae. In: R. M. Harley and T. Reynolds (eds.). Advances in Labiatae Science. Royal Botanic Gardens, Kew, London, pp. 7-17.

Heinig, R. L. 1925. List of Plants of the Chittagong Collectorate and Hill Tracts. Darjeeling, India, pp. 48-50. 
Heywood, V. H., R. K. Brummitt, A. Culham and O. Seberg. 2007. Flowering Plant Families of the World. Royal Botanic Gardens, Kew, London. 424 pp.

Hooker, J. D. 1885 (Repr. 1954). Labiatae. In: Hooker, J. D. The Flora of British India. Vol. 4. L. Reeve \& Co. Ltd., The Oast House, Brook, Ashford, Kent, England, pp. 604-705.

Hossain, M. M., M. A. Hassan and M. Z. Uddin. 2005. Checklist of angiospermic flora of Lalmai Hills, Comilla, Bangladesh. Bangladesh J. Plant Taxon. 12(2): 85-96.

Huq, A. M. and M. Begum. 1984. An Annotated List of climbers of Dacca. Bangladesh Agricultural Research Council, Dhaka, Bangladesh, pp. 1-7.

Huq, A. M. and M. S. Khan. 1984. A preliminary taxonomic report on the angiospermic flora of Moheskhali Island-1. Dhaka. Univ. Stud. Part B. 32(2): 19-31.

Huq, M. A. 1988. A preliminary taxonomic report on the angiospermic flora of Hatia Island (Noakhali district) (Dicotyledons). Bull. Bangladesh Natl. Herb. 1: 1-10.

Islam, M. R., M. Z. Uddin and M. A. Hassan. 2009. An assessment of the angiospermic flora of Ramgarh Upazilla of Khagrachari district, Bangladesh. Bangladesh J. Plant Taxon. 16(2): 115-140.

IUCN. 2012. IUCN Red List Categories and Criteria: Version 3.1. 2nd ed. Gland, Switzerland.

Judd, W. S., C. S. Campbell, E. A. Kellogg, P. E. Stevens and M. J. Donoghue. 2008. Plant Systematics: A Phylogenetic Approach. 3rd ed. Sinauer Associates, Massachusetts, USA. 611 pp.

Khan, M. S. 1991. Towards Sustainable Development: Conservation of Genetic Resources of Bangladesh. Ministry of Environment and Forests and National Conservation Strategy of Bangladesh, Agricultural Research Council. Dhaka, Bangladesh. 35 pp.

Khan, M. S. 2003. Flora. In: S. Islam, S. Miah, W. Ahmed, A. M. Chowdhury, S. M. M. Rahman, K. Siddiqui and S. M. H. Kabir (eds.). Banglapedia: National Encyclopaedia of Bangladesh. Vol. 4. Asiatic Society of Bangladesh, Dhaka, pp. 171-177.

Khan, M. S. and F. Banu. 1972. A taxonomic report on the angiospermic flora of Chittagong Hill Tracts2 (Dicotyledons). J. Asiatic Soc. Bangladesh. 17(2): 59-88.

Khan, M. S. and M. A. Huq. 2001. The vascular flora of Chunati wildlife sanctuary in south Chittagong, Bangladesh. Bangladesh J. Plant Taxon. 8(1): 47-64.

Khan, M. S. and S. K. Afza. 1968. A taxonomic report on the angiospermic flora of Teknaf and St. Martin's Island. Dacca Univ. Stud. 16(B): 25-30.

Khan, M. S., A. M. Huq, A. Hassan and M. M. Rahman. 1984. A taxonomic report on the angiospermic flora of St. Martin's Island. Dhaka Univ. Stud. B. 32(1): 71-84.

Khan, M. S., M. M. Rahman and M. A. Ali (eds.). 2001. Red Data Book of Vascular Plants of Bangladesh. Bangladesh National Herbarium, Dhaka. 179 pp.

Khan, M. S., M. M. Rahman, M. A. Huq, M. M. K. Mia and M. A. Hassan. 1994. Assessment of Biodiversity of Teknaf Game Reserve in Bangladesh focusing on economically and ecologically important plant species. Bangladesh J. Plant Taxon. 1(1): 21-33.

Khanam, M. 2009. Lamiaceae. In: Z. U. Ahmed, M. A. Hassan, Z. N. T. Begum, M. Khondker, S. M. H. Kabir, M. Ahmad, A. T. A. Ahmed, A. K. A. Rahman and E. U. Haque (eds.). Encyclopedia of Flora and Fauna of Bangladesh. Vol. 8. Angiosperms: Dicotyledons (Fabaceae-Lythraceae). Asiatic Society of Bangladesh, Dhaka, pp. 262-332. 
Khanam, M. and M. A. Hassan. 2005. A critical study of the genus Leucas R. Br. (Lamiaceae) from Bangladesh. Bangladesh J. Plant Taxon. 12(1): 1-10.

Khanam, M. and M. A. Hassan. 2008. Lamiaceae. In: M. Khanam and H. Ara (eds.). Flora of Bangladesh. Bangladesh National Herbarium, Dhaka. 161 pp.

Mabberley, D. J. 2008. Mabberley's Plant-book: A portable dictionary of plants, their classification and uses. 3rd ed. Cambridge University Press, New York. 1021 pp.

Momen, R. U., M. K. Hossain, S. M. Huda and B. M. Khan. 2006. Assessment of plant diversity in Chittagong University Campus. J. Forest. Environ. 4: 27- 52.

Mukerjee, S. K. 1940. A revision of the Labiatae of Indian Empire. Rec. Bot. Surv. India. 14(1): 1-228.

Naderuzzaman, A. T. M. and M. A. Islam. 1984. An Annotated list of trees of Rajshahi. Rajshahi Univ. Stud. B. 12: 1- 27.

Novacek, M. J. and E. E. Cleland. 2001. The current biodiversity extinction event: scenarios for mitigation and recovery. Proc. Natl. Acad. Sci. USA. 98(10): 5466-5470.

Pimm, S. L. and L. N. Joppa. 2015. How Many Plant Species are There, Where are They, and at What Rate are They Going Extinct? Ann. Missouri Bot. Gard. 100(3): 170-176.

Pitman, N. C. A. and P. M. Jorgersen. 2002. Estimating the Size of the World's Threatened Flora. Science. 298(5595): 989.

Prain, D. 1903. Bengal Plants. Vol. 2. Botanical Survey of India. Bishen Singh Mahendra Pal Singh, Dehra Dun, India, pp. 614-626.

Rahman, M. A. 2003. Some threatened forest species: IUCN Red List Categories. Biodiversity Newsletter Bangladesh. 7(1and2): 1-2.

Rahman, M. A. 2013. Red Data Book of Flowering plants of Bangladesh. Vol. 1. Chittagong-4000, Bangladesh, pp. 1-256.

Rahman, M. A. and M. E. Rashid. 2013. Status of endemic plants of Bangladesh and conservation management strategies. Int. J. Environ. 2(1): 231-249.

Rahman, M. A. and S. B. Uddin. 1997. Assessment of plant diversity of Sitakunda in Chittagong. Bangladesh J. Plant Taxon. 4(1): 17-36.

Rahman, M. A., M. N. Uddin, M. E. Rashid, M. N. Uddin and M. M. Islam. 2012. Floristic Diversity in Rampahar reserve forest of Kaptai, Rangamati. Biodiv. Bull. Bangladesh. 6: 1-31.

Rahman, M. A., S. C. Das and M. E. Rashid. 2010. The IUCN Red List Categories of angiosperm plants of Bangladesh and their conservation. J. Taxon. Biodiv. Res. 4: 17-34.

Rahman, M. M., M. H. Rashid and S. H. Rashid. 2001. Assessment of plant biodiversity of sand dune ecosystem along the Cox's Bazar to Teknaf coast. Bangladesh J. Plant Taxon. 8(1): 27-45.

Rahman, M.O. and M.A. Hassan. 1995. Angiospermic flora of Bhawal National Park, Gazipur (Bangladesh). Bangladesh J. Plant Taxon. 2(1and2): 47-80.

Rahman, M. O., M. Z. Uddin, E. Tutul, M. Begum and M. A. Hassan. 2010a. Additions to the angiospermic flora of Runctia Sal Forest, Bangladesh. Bangladesh J. Plant Taxon. 17 (2): 167-181.

Rashid, M. H. and M. A. I. Chowdhury. 2013. Additions to the Angiosperm flora in the Sitapahar Reserve Forest of Kaptai, Rangamati, Bangladesh. Bangladesh J.Plant Taxon. 20(2): 255-257. 
Rashid, M. H., E. Rahman and M. A. Rahman. 2000. Additions to the angiospermic flora of Moheskhali Island. Bangladesh J. Plant Taxon. 7(1): 43-63.

Rashid, M. H., M. E. Rashid and M. A. Rahman. 2014. Inventory of threatened plants of Bangladesh and their conservation management. Int. J. Environ. 3(1): 141-167.

Rashid, S. H. and M. M. K. Mia. 2001. Angiospermic flora of Madhupur National Park, Tangail, Bangladesh. Bangladesh J. Plant Taxon. 8(2): 63-82.

Sinclair, J. 1956. The Flora of Cox’s Bazar, East Pakistan. Bull. Bot. Soc. Beng. 9(2): 103- 104.

Tutul, E., M. Z. Uddin, M. O. Rahman and M. A. Hassan. 2010. Angiospermic flora of Runctia Sal Forest, Bangladesh-2. Magnoliopsida (Dicots). Bangladesh J. Plant Taxon. 17(1): 33-53.

Uberoi, N. K. 2010. Environmental Studies. (2nd ed). Excel Books Pvt. Ltd, New Delhi, India, pp. 1202.

Uddin, M. G., M. A. Rahman and M. E. Rashid. 2013. Plant diversity in Upper Rezu Reserve forest of Ramu, Cox's Bazar. Biod. Bull. Bangladesh. 7(1): 1-33.

Uddin, M. Z. and M. A. Hassan. 2004. Flora of Rema-Kalenga Wildlife Sanctuary. IUCN. Bangladesh Country office, Dhaka, Bangladesh, pp. 1-120.

Uddin, M. Z. and M. A. Hassan. 2010. Angiospermic Diversity of Lawachara National Park (Bangladesh): A preliminary assessment. Bangladesh J. Plant Taxon. 17(1): 9-22.

Uddin, M. Z., M. A. Hassan and M. S. Khan. 2003. An annotated Checklist of angiospermic flora of Rema-Kalenga Wildlife Sanctuary (Habiganj) in Bangladesh-IIa. Magnoliopsida (Dicots). Bangladesh J. Plant Taxon. 10(1): 79-94.

Uddin, M. Z., M. G. Kibria and M. A. Hassan. 2015. Assessment of angiosperm plant diversity of Nijhum Dweep. J. Asiat. Soc. Bangladesh, Sci. 41(1): 19-52.

Uddin, S. B. and M. A. Rahman. 1999. Angiospermic flora of Himchari National Park, Cox's Bazar. Bangladesh J. Plant Taxon. 6(1): 31-68.

Uddin, S. N., M. S. Khan, M. A. Hassan and M. K. Alam. 1998. An Annotated Checklist of angiospermic flora of Sitapahar at Kaptai in Bangladesh. Bangladesh J. Plant Taxon. 5(1):13-46.

USDA. 1993. Every Species Counts: Conserving Biological Diversity. Program Aid 1499. USDA Forest Service, Washington DC, USA.

Walter, K. S. and H. J. Gillett (eds.). 1998. 1997 IUCN Red List of Threatened Plants. World Conservation Monitoring Centre, the World Conservation Union (IUCN), Gland, Switzerland and Cambridge, UK. 862 pp.

Yusuf, M., M. O. Rahman, M. S. Khan and S. Huq. 1997. Angiospermic flora of Chanda Beel, Gopalganj district in Bangladesh. Bangladesh J. Plant Taxon. 4(2): 25-36. 